Bulletin de la Société des Sciences de Liège, Vol. 89, articles, 2020, p. 55 - 73

\title{
Integrated Coastal Zone Management (ICZM) Framework and Ecosystem Approach: eutrophication phenomenon at the Mediterranean Sea.
}

\author{
Manuscrit reçu le 24 mai 2019 et accepté le 20 septembre 2019 \\ Fátima KIES ${ }^{1, *}$, Manuel Monge-GanUZas ${ }^{2}$, Patricio De Los Rios ${ }^{3,4}$, \\ Isa O. ElEGBEDE ${ }^{5}$ and Cesare CORSELli ${ }^{1}$
}

\begin{abstract}
${ }^{1}$ Dipartimento di scienze dell'ambiente e del territorio e di scienze della terra, Universita degli studi di Milano-Bicocca, Piazza dell'Ateneo Nuovo, 1 - 20126, Milano, Italy.

${ }^{2}$ Service of the Urdaibai Biosphere Reserve. Basque goverment. Madariaga tower. GernikaBermeo road. San Bartolome. 48.350 BUSTURIA (Bizkaia, Basque Country, Spain).

${ }^{3}$ Departamento de Ciencias Biológicas y Químicas, Facultad de Recursos Naturales, Universidad Católica de Temuco, Casilla 15-D, Temuco, Chile

${ }^{4}$ Núcleo de Estudios Ambientales UCTemuco, Chile.

${ }^{5}$ Department of Environmental Planning, Brandenburg University of Technology, CottbusSenftenberg, Germany.
\end{abstract}

\begin{abstract}
The Mediterranean environment stressors and their effect on trophic state require the assessment of interconnection between land-based drivers, the real and potential pressures and impacts. To achieve this, it is necessary to consider as well, several social and economic factors that may influence decision-making around land-sea planning and the management of nutrient, pollutants and sediment transport. Moreover, once the ecological situation is characterized, it is advisable to establish the linking between the natural systems and the ecosystem services. In the Mediterranean Sea, it fairly demonstrated by ecosystem-based management approaches and the literature that human activities can affect the water column, the seafloor, and the biodiversity, among others. Moreover, it is a fact that these issues require a detailed piece of knowledge of a wide variety of geological, sociological, economical and biological variables, among others. Those variables are dependent on prioritises actions. One of them is the monitoring, mitigation and control of the eutrophication processes, which needs the deconstruction of the Integrated Coastal Zones Management (ICZM) approach into priorities actions, in accordance with the multi-level water characteristics and their interconnection, i.e., the coastal zone dynamics, and the multilevel governance.
\end{abstract}

*Author for correspondence, email : f.kies@,campus.unimib.it 
Bulletin de la Société des Sciences de Liège, Vol. 89, articles, 2020, p. 55 - 73

Key-words: Mediterranean Sea, eutrophication, Integrated Coastal Zone Management (ICZM), DPSIR, ecosystem approach.

\section{Introduction}

Water is one of the most sensitive elements of the environment and a prerequisite for human well-being and the development of its activities as it provides several ecosystem services (Piroddi et al. 2016). However, there are several factors that can influence its ecological status.

Human activities and climate change induced ecosystem vulnerability can provoke several coastal morphology changes that can also negatively influence on the land-ocean interface (Ochoa-Hueso et al. 2017), which is a particularly fragile, sensitive and complex environment. Thus, the effect induced by progressive anthropic changes on the hydrodynamic characteristics of the coastal and estuarine waters (Morrow et al. 2017), and as well on the ocean circulation (Grifoll et al. 2016), can lead to a high variability of marine biogeochemical processes, and cause negative impacts on the status and services of the near shore ecosystem, on which coastal societies depend. Moreover, these changes can drive to dramatic economic and human health impacts (Powley et al. 2014).

In the near shore in general, and specifically, in the Mediterranean Sea, due to the existing strong demographic and economic pressures and to other environmental drivers (i.e. wind speed, acidification, eutrophic depth, thermohaline depth, evaporation-precipitation abundance) the boundary status and the water column stability across the longitudinal environmental gradient can result directly impacted (Reygondeau et al. 2017). The tendency of the population to develop its activities on the coast - especially in the Mediterranean Sea - can increase the stress on its ecosystems and their surrounding areas and cause impacts on water quality and sediment characteristics, fauna diversity, flora richness, and their ecological interactions (Piroddi et al. 2017). Several examples can observe at some lagoons of Tunisia (Khedhri et al. 2016), lakes of Egypt (Abukila, 2015), rivers, estuaries, and littoral of Algeria (Kies and Kerfouf, 2014b), Spain (Grinyó et al. 2016), France (Kapsenberg et al. 2016), Italy (Katsanevakis et al. 2016), and Albania (Blanfuné et al. 2016).

Moreover, the Mediterranean Sea faces a variety of environmental problems, including habitat morphological alteration, water degradation, eutrophication, introduction of alien species, shoreline erosion, and increase of the surface water vulnerability (Maugendre et al. 2015) and the deep sea due to climate change induced sea level rise and ocean warming (Yasuhara and Danovaro, 2016), among others. These facts make necessary an integrated management strategy for this coastal zone (Zaucha et al. 2016).

As one of the biggest environmental problems for coastal waters is the over-enrichment in nutrients - i.e. eutrophication - from natural and/or anthropogenic inputs, this issue has become a topic of great interest. Eutrophication frequently results from natural (Laspidou et al. 2017), human actions such as domestic wastewater discharge, river damming, agricultural activities (Maavara et al. 2015), and production of biofuels from energy crops (Van Wijnen et al. 2015), 
which have an effect on water quality in rivers and coastal seas, and several ecosystem components and their ecosystem services (Colella et al. 2016).

In fact, serious eutrophication cases had been observed in the Mediterranean Sea, such as the ones of certain lagoons of Tunisia and France (Leruste et al. 2016), some estuaries and coastal zones of Spain (Aparicio et al. 2016), Greece (Pavlidou et al. 2015), among others.

The introduction of an excess of nutrients into the coastal areas results in a number of direct and/or indirect impacts (Coppens et al. 2016). The most common is eutrophication that can cause the following impacts: (1) overproduction of algal biomass (Bužančić et al. 2016); (2) loss of near shore habitat such as sea grass beds due to light reduction and soil erosion (Lopez-Merino et al. 2017); (3) variability in marine biodiversity, species distribution, and community composition (Abou Zaid et al. 2014; Pilotto et al. 2015); (4) reduction of water transparency due to increases in organic particles (Higueras et al. 2014); (5) and depletion of dissolved oxygen: hypoxia and anoxia (Segura-Noguera et al. 2016).

Furthermore, these effects can cause adverse impacts further up, along the trophic chains (Zoccarato and Umani, 2015) causing the death of pelagic and benthic fauna or at least, its disturbance. Some examples are the case of some shellfish affected by toxic phytoplankton species, and the apparition of microbial organisms that can impact directly and/or indirectly on the human health (Ridanovic et al. 2017). The aim of the present study will point out some environmental consequences of eutrophication and its relevance in the Mediterranean, in addition describe participatory approaches that should be involved to support the implementation of the Marine Strategy Framework Directive to manage the Mediterranean resources.

\section{Material and Methods}

Integrated Coastal Zone Management (ICZM) approach: ICZM (2012-2019) can be understood as a dynamic, multidisciplinary and interactive process to promote and guarantee the sustainable management of the littoral. It should include the ecosystem-based approach actions for the maintenance of the functionality of the coastal ecosystems for the reduction of human conflicts relative to management and/or use of resources (Santoso and Halog, 2017). In sum, a multisectorial approach towards the sustainable development seems to be necessary (Gambino et al. 2016) (Figure 1).

Moreover, ICZM should cover the full cycle of information collection, planning, decision making, management and monitoring of implementation and use the informed participation and cooperation process of all coastal stakeholders to assess the societal goals of a given coastal area and to take action towards meeting these objectives. ICZM seeks, over the long-run, to balance environmental, economic, social, cultural and recreational objectives, all inside the bounds set by natural dynamics (Potts et al. 2015; Freire-Gibb et al. 2014). 
Bulletin de la Société des Sciences de Liège, Vol. 89, articles, 2020, p. 55 - 73

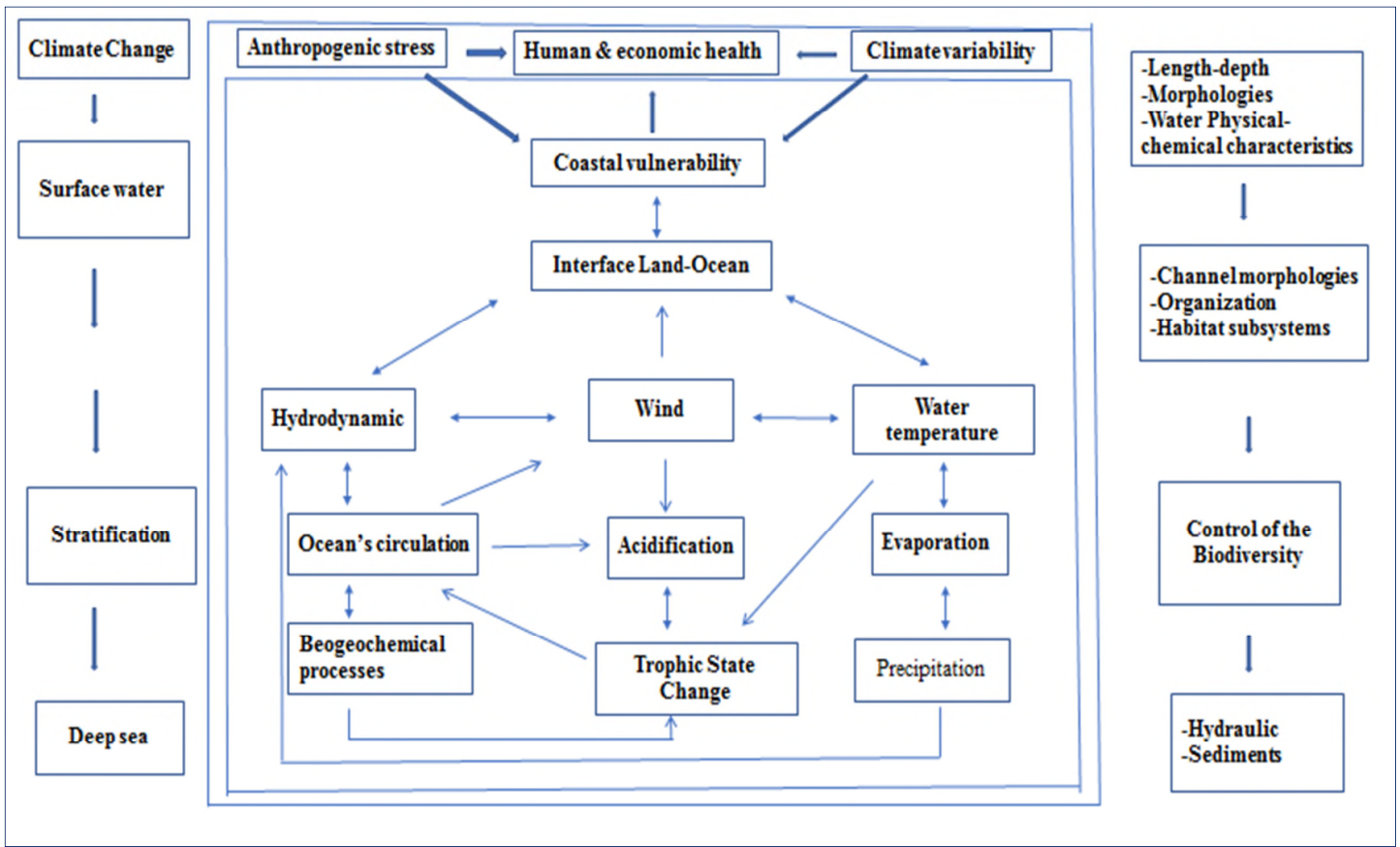

Figure 1: Conceptual diagram of human stressors and climate interactions on biogeochemical processes, effect on trophic state.

'Integrated' in ICZM can be relative to the integration of objectives and many instruments are needed to meet these objectives (Knežević and Petović, 2016). This fact implies all relevant policy areas, sectors, and levels of administration, which signifies the integration of the terrestrial and marine components of the target territory, in both, time and space. Defining the coastal zone is of particular importance to the implementation of ICZM. But the indistinctness of borders as a result of the dynamic nature of the coast makes it tough to obviously outline, especially in regard to the Mediterranean Sea.

ICZM at the Mediterranean Sea have been applied to achieve the Good Environmental Status (GEnS) of its ecosystems by 2020 (Knežević and Petović, 2016). (Figure 2).

It should conduct this part of the ocean towards a sustainable multi-dimension (local, national, regional, international, and temporal), ensuring the continuity of the futures generations and among others minimising the eutrophication (Annexe I of the Marine Directive, Descriptor 5). 
Bulletin de la Société des Sciences de Liège, Vol. 89, articles, 2020, p. 55 - 73

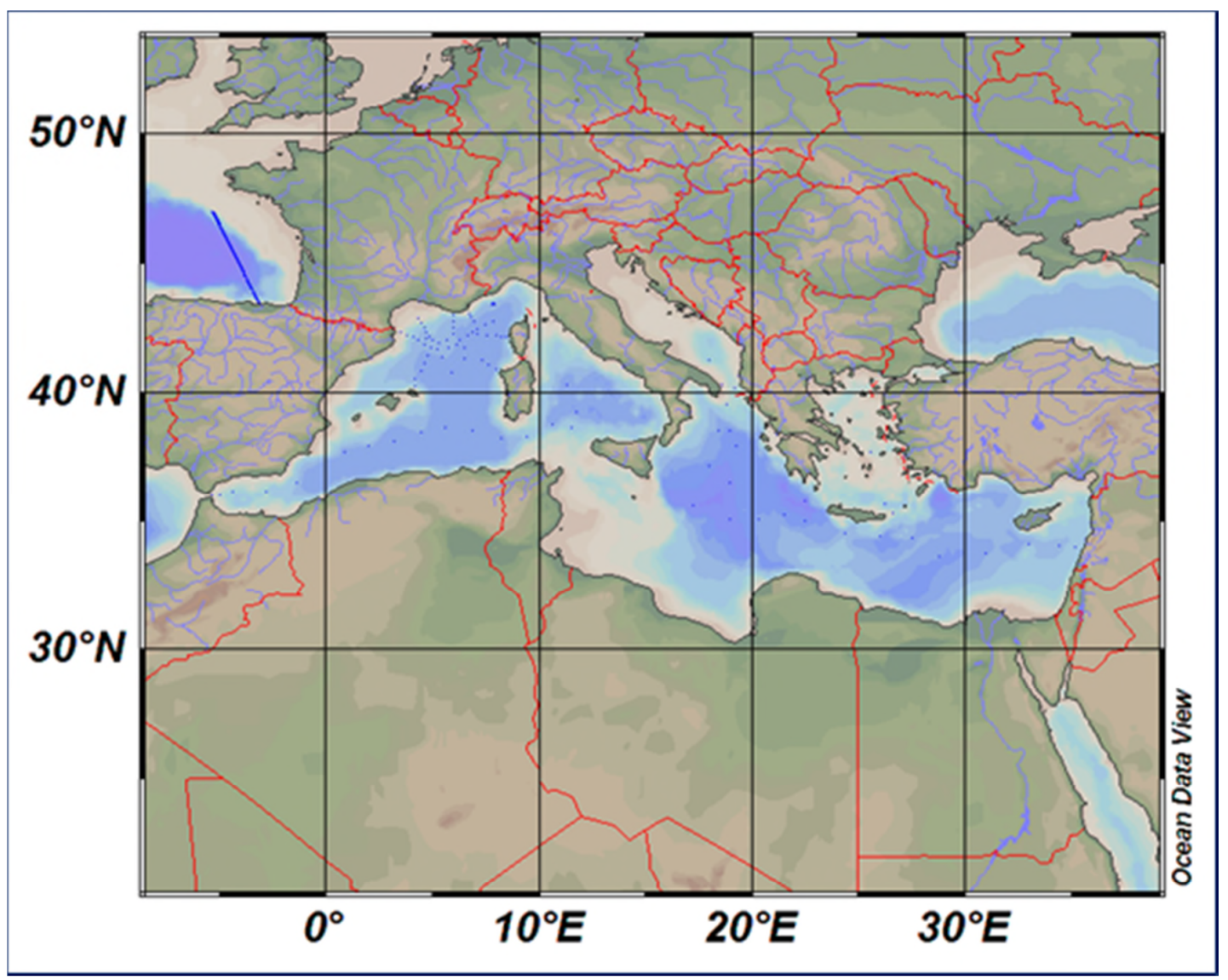

Figure 2: The Mediterranean Sea. The map was created using Ocean Data View (https://odv.awi.de).

The implementation of the Ecosystem Approach Process (2016-2021) at sensitive and vulnerable coastal areas (Jeppesen et al. 2017) such as the Mediterranean, in order to assess their status and as a basis for further and/or strengthened measures (La Notte et al. 2017), will allow countries to propose adequate measures to achieve the Good Environmental Status. In this way, ICZM could be implemented by the countries themselves taking into account their local specificities (Teixeira et al. 2014), focusing on innovation and blue growth based on ecosystem services (Karydis et al. 2015). Furthermore, it will bring more objectivity in the management of their coastal zones with the adoption of ecosystem approach in the coastal zones (Liquete et al. 2016).

A study case: Mediterranean Sea: common issues of the countries along the Mediterranean Sea are, the artificialization of the coast driver by over expanding tourism and urbanisation (Ghodbani and Berrahi-Midoun, 2013; Nakhli, 2010), the alteration of coastal dynamics and the degradation of its ecosystems and habitats (Roca et al. 2016), the increase of environmental risks along the coast, the loss and degradation of the landscape, the development of environmental problems due to aquaculture (Abdou et al. 2017) and the dwindling of the traditional fishery industry (Gambino et al. 2016), among others. 


\section{Results and Discussion}

Coastal issues interconnection: the patterns of climate inputs, and the population distribution and activities (Masria et al. 2014) underpin the variety between the 'type' and the 'intensity' of drivers and pressures (Table 1, Figure 3) across the four sub-regions of the Mediterranean.

Table 1: Assessment of land based Drivers, Pressures and Mediterranean and Estuaries Coastal Impacts.

\begin{tabular}{|c|c|c|c|c|c|}
\hline & & $\begin{array}{l}\text { South West } \\
\text { SW }\end{array}$ & $\begin{array}{l}\text { South East } \\
\text { SE }\end{array}$ & $\begin{array}{l}\text { North } \\
\text { West } \\
\text { NW }\end{array}$ & $\begin{array}{l}\text { North East } \\
\text { NE }\end{array}$ \\
\hline & & 4: Impacts/R & sponses (IR) & & \\
\hline \multirow{8}{*}{ 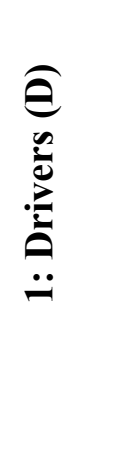 } & Agriculture & +++ & +++ & +++ & +++ \\
\hline & Urbanization & +++ & +++ & +++ & +++ \\
\hline & Industrialization & ++ & ++ & +++ & +++ \\
\hline & Deforestation & +++ & ++ & ++ & ++ \\
\hline & Damming/ diversion & ++ & +++ & ++ & ++ \\
\hline & Various & +++ & +++ & +++ & +++ \\
\hline & $\begin{array}{l}\text { Eutrophication/polluti } \\
\text { on }\end{array}$ & $\begin{array}{l}\text { Medium } \\
\text { (L.M) }\end{array}$ & Major & $\begin{array}{l}\text { Medium } \\
\text { (L.M) }\end{array}$ & Major \\
\hline & Nutrients depletion & Medium & Medium & Medium & Medium \\
\hline \multirow{4}{*}{ 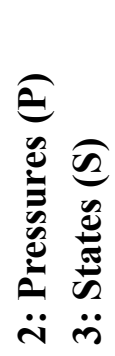 } & $\begin{array}{l}\text { Erosion/Sedimentatio } \\
\mathrm{n}\end{array}$ & Major & Major & Major & Major \\
\hline & Biodiversity loss & Major & Major & Major & Major \\
\hline & Pollution & Medium & Medium & Major & Major \\
\hline & Salinization & Major & $\begin{array}{l}\text { Medium } \\
\text { (L.M) }\end{array}$ & Major & Major \\
\hline
\end{tabular}

Very important: +++; +/- important: ++; and less important: +; L.M: Local Major 
Bulletin de la Société des Sciences de Liège, Vol. 89, articles, 2020, p. 55 - 73

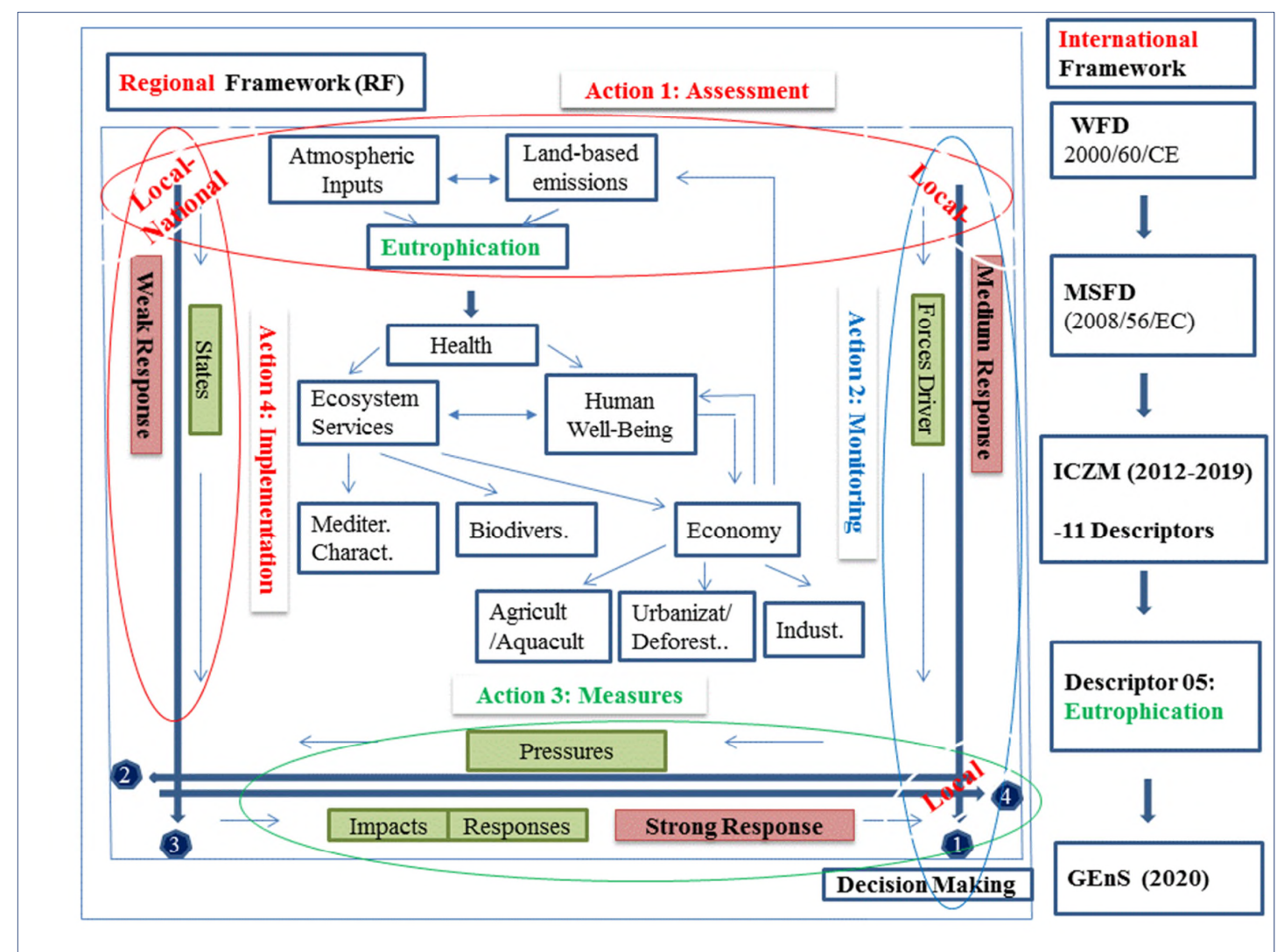

Figure 3: Integrated analysis of eutrophication: Conceptual model describing the linking between Ecosystem services, human well-being, and the complex ecosystem effects of Eutrophication within the Integrated Coastal and Estuarine Zones (Mediterranean Sea).

Agriculture and deforestation are contributing to significant increases in soil erosion and consequently increased sediment fluxes and discharge (Serra et al. 2008). Agriculture, together with urbanization and industrialization is provoking the degradation of the waters that discharges into estuaries and coastal seas. This fact loads to growing problems of pollution and eutrophication (Abdou et al. 2017). Industrialization coupled with deforestation can generate the aggravation of the Mediterranean environment problems and consequently provoke impacts over human health. All the socio-economic drivers referred play a part in the reported loss of biodiversity throughout the region, principally through the destruction of habitat and reduction in the volume and the quality of freshwater discharge through the coastal zone to the coastal sea. Diversion and damming usually in association with agriculture and locally intense urbanization are principal drivers for a coastal charge (Abdou et al. 2017). Increasing industrial developments, coastal urbanization, and high density coastal population add further pressures. Deforestation in upper catchments is a continuing concern.

The approach for the integrated analysis of ecosystem and human health, request a complex analysis using the Drivers-Pressures-State-Impact-Response (DPSIR) framework. The coastal 
zone of the sparsely populated northern sub-region of the Mediterranean sustains anthropogenic pressures from coastal urban areas and industrial development, these represents the major drivers and modifications such as changes in the shorelines of the Mediterranean countries (Pilotto et al. 2015) and the relation with the multi-level changes in the regional and global circulation (Cossarini et al. 2017) and cycles as well as changes in sea level and wave regimes (Peyron et al. 2016). The most significant impact derived from the rapid economic growth in the lakes (Ferriol et al. 2016) and rivers basins is increased nitrogen loading to the coast (Kies, 2015). Pronounced state changes in the receiving marine environments of the rivers and estuaries result from eutrophication yielding algal blooms, oxygen depletion, contamination of water quality and the ecosystem components (Kies, 2015). The Dinoflagellate bloom of Gymnodinium sp and Dinophysis $s p$ resulted in the loss of demersal and benthic fish stock, and the disturbance of macro-invertebrates (Leung, 2015).

Marine policies: for several decade, eutrophication (Figure 3) has been an international environmental concern in Europe which lead to the regional framework (RF) addressing the problem including the Barcelona Convention or MEDPOL for the Mediterranean (Ferreira et al. 2011). The two relevant European legislative frameworks that influence on this issue are the 2000 EU Water Framework Directive (WFD) "Directive 2000/60/EC" and the 2008 EU Marine Strategic Framework Directive (MSFD) "Directive 2008/56/EC" (Van Hoey et al. 2010). Whereas the WFD is limited to the territorial estuarine and coastal waters, stretching $12 \mathrm{~m}$ from the coast, the MSFD applies to the marine waters, stretching the $200 \mathrm{~m}$ limit of the Exclusive Economic Zone. The adequate implementation of these legislative agreements (Reyjol et al. 2014) depends on a proper definition of the phenomenon as well as measurable and practical indicators (Freire-Gibb et al. 2014). The MSFD is aimed at achieving a GEnS by 2020, following an ecosystem-based approach (Berg et al. 2015), and addresses the problem of climatic and human-induced eutrophication as one of eleven environmental quality descriptors which should be used in combination to assess the environmental status of marine (Cochrane et al. 2016), transitional and coastal waters. These eleven descriptors are: biological diversity, non-indigenous species, commercial fish, food webs, eutrophication, sea floor, hydro-geographical conditions, contaminants and pollution effects, contaminants in fish and other seafood, litter, and energy/noise (Noges et al. 2016).

The MSFD eutrophication quality descriptor refers to the adverse effects of eutrophication including "losses in biodiversity, ecosystem degradation, harmful algae blooms and oxygen deficiency in bottom waters" (Noges et al. 2016). According to UNEP/MAP, 2007, the assessment and monitoring of the eutrophication in the Mediterranean Sea requires monitoring parameters for the indicators (COM DEC 2010/477/EU) of eutrophication only for the Mediterranean Coastal waters (WFD) which are, Nutrients concentration in the water column (5.1.1); Nutrient ratios (silica, nitrogen and phosphorus), where appropriate (5.1.2); Chlorophyll concentration in the water column (5.2.1); Dissolved oxygen, i.e. changes due to increased organic matter decomposition and size of the area concerned (5.3.2). 
Causes and consequences of eutrophication in multi-level: the main causes of eutrophication are the atmospheric inputs and land-based emissions, stages of the process driven (drivers) by over-enrichment of water by nutrients (medium response), especially compounds of nitrogen and/or phosphorus (pressures), leading to the increase growth primary production (weak Response) and biomass of algae (state); changes in the balance of organisms, and water quality degradation (impact), causing degradation of the health of the ecosystem services (strong response) which has an impact directly and/or indirectly on Mediterranean water characteristics, disturbance of the biodiversity community, economic imbalance affecting the different activities which human life depend such as the agriculture, aquaculture, fishing, urbanization/deforestation, and industrialization, it means impact directly and/or indirectly human well-being (strong Response). According to the literature, in the national level, the intensity of responses considers weak comparing to the local level, where the intensity of responses ranges between medium and strong (local Major) depend the environment types and intensity impact (Table 1, Figure 3 ).

Priorities actions to manage eutrophication in Mediterranean multi-level scales: the Mediterranean has multi-level scales, that requires prioritises actions to manage eutrophication, which needs the deconstruction of the ICZM into different priorities action in accordance with the level scale.

By Assessment in the local and National level (Weak to Medium Response), of the functioning of nutrients especially compounds of nitrogen and/or phosphorus in relation to drivers/pressures; and holistic monitoring in the local level (strong Response) of changes in the balance of organisms, and water quality degradation causing degradation of the health of the ecosystem services and human well-being; and measures in the local level (Medium to Strong Response) of growth primary production and biomass of algae, in the sensitives areas discharges such as basin rivers, estuaries, lacks, and lagoons (Basset et al. 2013), causing eutrophication process affecting surrounding zones, causing degradation of the economic and human health; needing implementation of projects oriented at solving priority environment and sustainable development related problems of some hot spots for eutrophication in selected areas (local level), contributing to the formulation and implementation (national level) of relevant national policies and strategies with projects results and solutions proposed (the implementation of ICZM, Descriptor 5 related to the eutrophication, and indirectly by offering methodologies and procedures tested under specific local conditions and national instruments such as big data phytoplankton (Robinson et al. 2017), phytoplankton community "Chlorophyll a" (Mangoni et al. 2016), and Data Eutrophication Management, Geospatial Data and Metadata (Pons and Maso, 2016), land-use planning, sea-use planning, norms, standards, economics instruments, to achieve a GEnS. The Trophic Index "TRIX" (Vollenweider et al. 1998) that was proposed for assessment and monitoring of the eutrophication in the Mediterranean Sea requires data on Chlorophyll a, oxygen saturation, dissolved inorganic nitrogen and dissolved inorganic phosphorus, but the literature demonstrate the inefficacy of TRIX as a reliable tool to classify eutrophication status in transitional waters (Salas et al, 2008). In addition, data about hydrodynamic and hydro-chemical parameters, 
Bulletin de la Société des Sciences de Liège, Vol. 89, articles, 2020, p. 55 - 73

hydrogeology parameters, biomass and abundance of zooplankton, benthic invertebrates, coastal fish length should be monitored (Pons and Maso, 2016).

The adoption of a multidisciplinary approach, covering the different fields involved in designating and assessing transitional, coastal, and marine waters. Ecosystem-based management of activities affecting water-column, seafloor, and their biodiversity, requiring knowledge of a wide variety of ecological and biological variables (Danovaro et al. 2017) such as the multi-level water characteristics and their interconnection, biodiversity, life cycles, functional variables, trophic interactions, and organic-matter cycling, supported by abiotic measurements and (Noges et al. 2016) detailed habitat mapping (Valle et al. 2015) by disseminating the results and experience achieved contributing to the formulation and implementation of relevant regional policies and strategies, at a wider multi-level water governance systems and International Relations (Daniell et al. 2014), and transnational threats and risks in Organizations and Time, requiring knowledge-based management (O'Brien et al. 2016), by co-operating, exchanging, and offering results, methodologies and procedures to other regions, evaluation and assessment techniques including environmental impact assessment in better times, forecast and modelling tourism capacity, strategies, climate changes and vulnerability assessment of landscapeseascape/territory.

\section{Acknowledgements}

The present study was founded by project MECESUP UCT 0804, and the authors express their gratitude to M.I., and S.M.A for their valuable comments for the improvement of the manuscript.

\section{References}

Abdenadher M., Hamza A., Fekih W., Hannachi I., Zouari Bellaaj A., Bradai M., \& Aleya L., 2012. Factors determining the dynamics of toxic blooms of Alexandrium minutum during a 10-year study along the shallow southwestern Mediterranean coasts. Estuarine, Coastal and Shelf Science 106: 102-111

Abdou K., Aubin J., Romdhane M.S., . Le Loc'h F., \& Lasram, F.B.R. 2017. Environmental assessment of seabass (Dicentrarchus labrax) and seabream (Sparus aurata) farming from a life cycle perspective: A case study of a Tunisian aquaculture farm. Aquaculture, 471: 204212.

Abou Zaid M.M., El Raey M., Aboul Ezz S.M., Abdel Aziz N.E., \& Abo-Taleb H.A., 2014. Diversity of Copepoda in a Stressed Eutrophic Bay (El-Mex Bay), Alexandria, Egypt. The Egyptian Journal of Aquatic Research, 40: 143-162

Abukila, A.F., 2015. Assessing the drain estuaries' water quality in response to pollution abatement. Water Science, 29: 1-18.

Aparicio F.L., Nieto-Cid M., Borrull E., Calvo E., Pelejero C., Sala M., Pinhassi M., Gasol J.M., \& Marrasé C., 2016. Eutrophication and acidification: Do they induce changes in the dissolved organic matter dynamics in the coastal Mediterranean Sea?. Science of the Total Environment 563/564: 179-189

Basset A., Barbone E., Borja A., Elliott M., Jona-Lasinio G., Marques J.C., Mazik K., Muxika I., 
Bulletin de la Société des Sciences de Liège, Vol. 89, articles, 2020, p. 55 - 73

Magalhaes Neto, J., Reizopoulou, S., Rosati L., \& Teixeira H., 2013. Natural variability and reference conditions: Setting type-specific classification boundaries for lagoon macroinvertebrates in the Mediterranean and Black Seas. Hydrobiologia, 704: 325-345.

Berg, T., Fürhaupter K., Teixeira H., Uusitalo L., \& Zampoukas N., 2015. The Marine Strategy Framework Directive and the ecosystem-based approach - pitfalls and solutions. Marine Pollution Bulletin, 96: 18-28.

Blanfuné A., Boudouresque C.F., Verlaque M., Beqiraj S., Kashta L., Nasto L., Ruci S., \& Thibaut, T., 2016. Response of rocky shore communities to anthropogenic pressures in Albania (Mediterranean Sea): Ecological status assessment through the CARLIT method. Marine Pollution Bulletin, 109: 409-418.

Bužančić M., Ninčević Gladan Z., Marasović L., Kušpilić G., \& Grbec B., 2016. Eutrophication influence on phytoplankton community composition in three bays on the eastern Adriatic coast. Oceanologia, 58: 302-316.

Candela J., 2001. Chapter 5.7 Mediterranean water and global circulation. International Geophysics. 77: 417-429.

Cardoso A.C., Cochrane S., Doerner H., Ferreira J.G., Galgani F., Hagebro C., Hanke C., Hoepffner N., Keizer P., Robin L., Olenin S., Piet G., Rice J., Rogers S., Swartenbrooux F., Tasker M., \& Van de Bund W., 2010 International Council for the Exploration of the Sea (ICES). (2010). Scientific support to the European Commission Marine Strategy Framework Directive: management group report, March 2010. Publications Office. Retrieved from http://publications.jrc.ec.europa.eu/repository/handle/JRC58097

Ćetkovic, J. (n.d.). Study on the institutional Framework for sustainable coordination of Integrated Coastal Zone Management of Montenegro with a proposal for institutional reorganization. Retrieved from http://www.shape-ipaproject.eu/download/listbox/WP3 action 3.4/Montenegro - governance structure.pdf

Cochrane, S.K.J., Andersen J.H., Berg T., Blanchet H., Borja A., Carstensen J., Elliot M., Hummel, H., Niquil N., \& Renaud P.E.,2016. What Is Marine Biodiversity? Towards Common Concepts and Their Implications for Assessing Biodiversity Status. Frontiers in Marine Science, 3: 1-14

Colella S., Falcini F., Rinaldi E., Sammartino M., \& Santoleri R., 2016. Mediterranean ocean colour chlorophyll trends. PLoS ONE. http://doi.org/10.1371/journal.pone.0155756

Coppens J., Özen, A., Tavşanoğlu Ü.N., Erdoğan Ş., Levi E.E., Yozgatlıgil C., Jeppensen E., \& Beklioğlu M., 2016. Impact of alternating wet and dry periods on long-term seasonal phosphorus and nitrogen budgets of two shallow Mediterranean lakes. Science of The Total Environment, 563-564 : 456-467.

Cossarini G., Querin S., Solidoro C., Sannino G., Lazzari P., DI Biagio V., \& Bolzon G., 2017. Development of BFMCOUPLER (v1.0), the coupling scheme that links the MITgcm and BFM models for ocean biogeochemistry simulations. Geoscientific Model Development, 10 : $1423-1445$.

Daniell K.A., Coombes P.J., \& White I., 2014. Politics of innovation in multi-level water governance systems. Journal of Hydrology, 519: 2415-2435. 
Bulletin de la Société des Sciences de Liège, Vol. 89, articles, 2020, p. 55 - 73

Danovaro R., Aguzzi J., Fanelli E., Billett D., Gjerde K., Jamieson A., Ramirez-Llodra E., Smith C.R., Snelgrove P.V.R., Thomsen L., \& Dover C.L., 2017. An ecosystem-based deep-ocean strategy. Science, 355: 452-454.

Danovaro R, \& Pusceddu A., 2007. Ecomanagement of biodiversity and ecosystem functioning in the Mediterranean Sea: concerns and strategies. Chemistry and Ecology, 23: 347-360.

El-Raey M., Dewidar K., \& El-Hattab M., 1999. Adaptation to the Impacts of Sea Level Rise in Egypt. Mitigation and Adaptation Strategies for Global Change, 4: 343-361.

El-Zeiny A., \& El-Kafrawy S., 2017. Assessment of water pollution induced by human activities in Burullus Lake using Landsat 8 operational land imager and GIS. The Egyptian Journal of Remote Sensing and Space Science, 20: S49-S56.

Ferriol C., Miracle M.R., \& Vicente E., 2016 Effects of nutrient addition, recovery thereafter and the role of macrophytes in nutrient dynamics of a Mediterranean shallow lake: a mesocosm experiment. Marine and Freshwater Research 68: 506-511

Ferreira J.G., Andersen J.H., Borja A., Bricker S.B., Camp J., Cardoso da Silva M., Garcés E., Heiskanen A-S., Humborg C., Ignatiades L., Lancelot C., Menesguen A., Tett P., Hoepffner N., \& Claussen U., 2011. Overview of eutrophication indicators to assess environmental status within the European Marine Strategy Framework Directive. Estuarine, Coastal and Shelf Science, 93: 117-131.

Freire-Gibb L.C., Koss R., Margonski P., \& Papadopoulou N., 2014. Governance strengths and weaknesses to implement the marine strategy framework directive in European waters. Marine Policy, 44: 172-178.

Gambino M., Accadia P., Pinello D., Russo T., Malvarosa L., Sabatella E.C., Cozzolino M., \& Sabatella R.F., 2016. Towards an Integrated Coastal Zone Management in Campania Region (Italy): A Multidisciplinary Approach to the Analysis of Coastal Fishery Activities and their Socio-Economic Management. Procedia - Social and Behavioral Sciences, 223: 342-348.

García-Altares M., Casanova A., Fernández-Tejedor M., Diogène J., \& de la Iglesia P., 2016. Bloom of Dinophysis spp. dominated by D. sacculus and its related diarrhetic shellfish poisoning (DSP) outbreak in Alfacs Bay (Catalonia, NW Mediterranean Sea): Identification of DSP toxins in phytoplankton, shellfish and passive samplers. Regional Studies in Marine Science, 6: 19-28.

Ghodbani T., \& Berrahi-Midoun, F., 2013. La littoralisation dans l'Ouest algérien: analyse multiscalaire des interactions hommes-espaces-écosystèmes. Espace Populations Sociétés, 2013/1-2 : 231-243.

Grifoll M., Del Campo A., Espino M., Mader J., González M., \& Borja A., 2013. Water renewal and risk assessment of water pollution in semi-enclosed domains: Application to Bilbao Harbour (Bay of Biscay). Journal of Marine Systems, 109-110: s241-s251

Grifoll M., Navarro J., Pallares E., Ràfols L., Espino M., \& Palomares A., 2016. Oceanatmosphere-wave characterisation of a wind jet (Ebro shelf, NW Mediterranean Sea). Nonlinear Processes in Geophysics, 23: 143-158.

Grinyó J., Gori A., Ambroso S., Purroy A., Calatayud C., Dominguez-Carrió C., Coppari M., Lo Iacono C., López-González J., \& Gili J.-M., 2016. Diversity, distribution and population 
Bulletin de la Société des Sciences de Liège, Vol. 89, articles, 2020, p. 55 - 73

size structure of deep Mediterranean gorgonian assemblages (Menorca Channel, Western Mediterranean Sea). Progress in Oceanography, 145: 42-56.

Higueras M., Kerhervé P., Sanchez-Vidal A., Calafat A., Ludwig W., Verdoit-Jarraya M., Heussmer S., \& Canals M., 2014. Biogeochemical characterization of the riverine particulate organic matter transferred to the NW Mediterranean Sea. Biogeosciences, 11: 157-172.

Kapsenberg L., Alliouane S., Gazeau F., Mousseau L., \& Gattuso J.-P., 2016. Concomitant ocean acidification and increasing total alkalinity at a coastal site in the NW Mediterranean Sea (2007-2015). Ocean Science Discussions, 13: 1-43.

Karydis M., Kitsiou D., Kostopoulou M., \& Pavlogeorgatos G., 2015. Ecosystem services and spatial planning in sensitive and vulnerable coastal areas: a case study in the Aegean sea, 35. Retrieved from: http://cest2015.gnest.org/papers/cest2015 00045 oral paper.pdf

Katsanevakis S., Tempera F., \& Teixeira H., 2016. Mapping the impact of alien species on marine ecosystems: the Mediterranean Sea case study. Diversity and Distributions, 22: 694707.

Khakzad S., Pieters M., \& Van Balen K., 2015. Coastal cultural heritage: A resource to be included in integrated coastal zone management. Ocean and Coastal Management, 118: $110-128$.

Khedhri I., Atoui A., Ibrahim M., Afli A., \& Aleya L., 2016. Assessment of surface sediment dynamics and response of benthic macrofauna assemblages in Boughrara Lagoon (SW Mediterranean Sea). Ecological Indicators, 70: 77-88.

Kies F., 2015. Assessment of surface water chemistry and algal biodiversity in the Bay of Mostaganem and the Cheliff estuary: North-western Algeria. Sustainability, Agri, Food and Environmental Research, 3: 1-16. http://hdl.handle.net/10281/156700

Kies F., \& Kerfouf A., 2014a. Impact of the climate change on the West coast of Algeria: Gulf of Oran, Arzew and Mostaganem. Sustainability, Agri, Food and Environmental Research, 2: $1-15$.

Kies F., \& Kerfouf A., 2014a. Physico-chemical characterization of surface waters of the west coast of Algeria: Bay of Mostaganem and Cheliff estuary. Sustainability, Agri, Food and Environmental Research, 2: 1-10.

Kies F., Mezali K., \& Soualili D.L., 2012. Modélisation sous R de la pêcherie et des flux de nutriments Modélisation sous R de la pêcherie de Mostaganem et des flux de nutriments (N, $\mathrm{P}, \mathrm{Si}$ ) de l'Oued Chéliff (Algérie). Éditions Universitaires Européenes. http://hdl.handle.net/10281/127169

Kies F., \& Taibi N., 2011. Influence de L Oued Cheliff Sur L Ecosysteme Marin. Edition Universitaire Europeenne. Retrieved from https://www.bookdepository.com/Influence-de-LOued-Cheliff-Sur-L-Ecosysteme-Marin-Fatima-Kies/9786131589669

Knežević J., \& Petović S., 2016. Integrated Coastal Zone Management in Boka Kotorska Bay (pp. 573-587). Springer International Publishing.

La Notte A., D’Amato D., Mäkinen H., Paracchini L.M., Liquete C., Egoh B., Geneletti D., \& Crossman N.D., 2017. Ecosystem services classification: A systems ecology perspective of 
Bulletin de la Société des Sciences de Liège, Vol. 89, articles, 2020, p. 55 - 73

the cascade framework. Ecological Indicators, 74: 392-402.

Laspidou C., Kofinas D., Mellios N., Latinopoulos D., \& Papadimitriou T., 2017. Investigation of factors affecting the trophic state of a shallow Mediterranean reconstructed lake. Ecological Engineering, 103: 154-163

Leruste A., Malet N., Munaron D., Derolez V., Hatey E., Collos Y., \& Bec B., 2016. First steps of ecological restoration in Mediterranean lagoons: Shifts in phytoplankton communities. Estuarine, Coastal and Shelf Science, 180: 190-203.

Leung J.Y.S., 2015. Habitat heterogeneity affects ecological functions of macrobenthic communities in a mangrove: Implication for the impact of restoration and afforestation. Global Ecology and Conservation, 4: 423-433.

Liquete C., Piroddi C., Macías D., Druon J.-N., \& Zulian G., 2016. Ecosystem services sustainability in the Mediterranean Sea: assessment of status and trends using multiple modelling approaches. Scientific Reports, 6: 34162.

Lopez-Merino L., Colas-Ruiz N.R., Adame M.F., Serrano O., Martinez Cortizas A., \& Mateo M.A., 2017. A six thousand-year record of climate and land-use change from Mediterranean seagrass mats. Journal of Ecology 105: 1-12.

Maavara T., Parsons C.T., Ridenour C., Stojanovic S., Dürr H.H., Powley H., \& Van Cappellen P., 2015. Global phosphorus retention by river damming. Proceedings of the National Academy of Sciences of the United States of America, 112: 15603-8.

Mangoni O., Lombardo O., Camminatiello L., Margiotta F., Passarelli A., \& Saggiomo M., 2016. Phytoplankton community to assess the environmental status of the Adriatic Sea via nonlinear partial least squares regression The environmental status of the Adriatic Sea. Quality and Quantity, 51: 799-812.

Maugendre L., Gattuso J-P., Louis J., de Kluijver A., Marro S., Soetaert K., \& Gazeau F., 2015. Effect of ocean warming and acidification on a plankton community in the NW Mediterranean Sea. ICES Journal of Marine Science: Journal du Conseil, 72: 1744-1755.

Masria A., Negm A., Iskander M., \& Saavedra O., 2014. Coastal Zone Issues: A Case Study (Egypt). Procedia Engineering, 70: 1102-1111.

Morrow R., Carret A., Birol F., Nino F., Valladeau G., Boy F., Bachelier C., \& Zakardjian B., 2017. Observability of fine-scale ocean dynamics in the northwestern Mediterranean Sea. Ocean Science, 13: 13-29.

Nakhli S., 2010. Pressions environnementales et nouvelles stratégies de gestion sur le littoral marocain. Méditerranée, 115: 31-42.

Nehar B., 2016. Contribution à l'Etude des Diatomées Benthiques de quelques cours d'eau de 1'Oranie: Taxonomie et Ecologie. Université d'Oran. Retrieved from http://theses.univoran1.dz/document/132016117t.pdf

Nehar, B., Blanco S., \& S. Hadjadj-Aoul, 2015. Diversity and ecology of diatoms in Northwest of Algeria: case of El-Hammam Stream and Estuary of Cheliff River. Applied Ecology and Environmental Research 13: 37-52.

Noges P., Argillier C., Borja A., Garmendia J.M., Hanganu J., Kodes V., Saqouis A. \& Birk S., 2016. Quantified biotic and abiotic responses to multiple stress in freshwater, marine and 
Bulletin de la Société des Sciences de Liège, Vol. 89, articles, 2020, p. 55 - 73

ground waters. Science of the Total Environment, 540: 43-52.

O'Brien A., Townsend K., Hale R., Sharley D., \& Pettigrove V., 2016. How is ecosystem health defined and measured? A critical review of freshwater and estuarine studies. Ecological Indicators, 69: 722-729.

Ochoa-Hueso R., Munzi S., Alonso R., Arróniz-Crespo M., Avila A., Bermejo V., Bobbink R., Branquinho C., Concostrina-Zubiri L., Cruz C., Cruz de Carvalho R., De Marco A., Dias T., Elustondo D., Elvira S., Estébanez E., Fussaro L., Gerosa G., Izquieta-Rojano S., Lo Cascio M., Marzouli R., Matos P., Mereu S., Merino J., Morillas L., Nunes A., Paoletti E., Paoli L., Pinho P., Rogers I.B., Santos A., Siccard P., Stevens C.J., \& Theobald M.R., 2017. Ecological impacts of atmospheric pollution and interactions with climate change in terrestrial ecosystems of the Mediterranean Basin: Current research and future directions. Environmental Pollution, 227: 194-206.

Pascual M., Borja A., Galparsoro L., Ruiz J., Mugerza E., Quincoces L., Murillas A., \& Arregi L., 2013. Total fishing pressure produced by artisanal fisheries, from a Marine Spatial Planning perspective: A case study from the Basque Country (Bay of Biscay). Fisheries Research, 147: 240-252

Pavlidou A., Simboura N., Rousselaki E., Tsapakis M., Pagou K., Drakopoulou P., Assimakopoulou G., Kontoyioannis H., \& Panayotidis P., 2015. Methods of eutrophication assessment in the context of the water framework directive: Examples from the Eastern Mediterranean coastal areas. Continental Shelf Research, 108: 156-168.

Peyron O., Combourieu-Nebout N., Brayshaw D., Goring S., Andrieu-Ponel V., Desprat S., Fletcher W., Gambin B., Ioakin C., Joannin S., Kotthof U., Kouli K., Montade V., Porss J., Sadori L., \& Magny M., 2016. The climate of the Mediterranean basin during the Holocene from terrestrial and marine pollen records: A model/data comparison. Climate of the Past Discussions, (March), 1-33.

Pharino C., Sailamai N., \& Kamphaengthong P.L., 2016. Material Flow Analysis of Nitrogen in Maeklong River Basin in Ratchaburi and Samut Songkhram Province, Thailand. Water Conservation Science and Engineering, 1: 167-175.

Pilotto F., Bazzanti M., Di Vito V., Frosali D., Livretti F., Mastrantuono L., Push M.T., Sena F., \& Solimini A.G., 2015. Relative impacts of morphological alteration to shorelines and eutrophication on littoral macroinvertebrates in Mediterranean lakes. Freshwater Science, 34: 410-422.

Piroddi C., Coll M., Liquete C., Macias D., Greer K., Buszowski J., Steenbeek J., Danovaro R., \& Christensen V., 2017. Historical changes of the Mediterranean Sea ecosystem: modelling the role and impact of primary productivity and fisheries changes over time. Scientific Reports, 7: 44491.

Piroddi C., Moutopoulos D.K., Gonzalvo J., \& Libralato S., 2016. Ecosystem health of a Mediterranean semi-enclosed embayment (Amvrakikos Gulf, Greece): Assessing changes using a modeling approach. Continental Shelf Research, 121: 61-73.

Poikane S., Zampoukas N., Borja A., Davies S.P., van de Bund W., \& Birk S., 2014. Intercalibration of aquatic ecological assessment methods in the European Union: Lessons 
Bulletin de la Société des Sciences de Liège, Vol. 89, articles, 2020, p. 55 - 73

learned and way forward. Environmental Science and Policy, 44: 237-246.

Pons X., \& J. Maso, 2016. A comprehensive open package format for preservation and distribution of geospatial data and metadata. Computers and Geosciences, 97: 89-97.

Potts T., O’Higgins T., Brennan R., Cinnirella S., Brandt U.S., Suárez de Vivero J.L., Beusekom J.J., Troost T.A., Paltriguera L., \& Hosgor A.G., 2015. Detecting critical choke points for achieving Good Environmental Status in European seas. Ecology and Society, 20: art29.

Powley H.R., Dürr H.H., Lima A.T., Krom M.D., \& Van Cappellen P., 2016a. Direct Discharges of Domestic Wastewater are a Major Source of Phosphorus and Nitrogen to the Mediterranean Sea. Environmental Science and Technology, 50: 8722-8730.

Powley H.R., Krom M.D., Emeis K.C., \& P. Van Cappellen, 2014. A biogeochemical model for phosphorus and nitrogen cycling in the Eastern Mediterranean Sea: Part 2. Response of nutrient cycles and primary production to anthropogenic forcing: 1950-2000. Journal of Marine Systems, 139: 420-432.

Powley H.R., Krom M.D., \& Van Cappellen P., 2016b. Circulation and oxygen cycling in the Mediterranean Sea: Sensitivity to future climate change. Journal of Geophysical Research: Oceans, 121: 8230-8247.

Rentsch J.R., Small E.E., \& Team U., 2007. Multi-Level Issues in Organizations and Time. Research in Multi-Level Issues.

Reygondeau G., Guieu C., Benedetti F., Irisson J.O., Ayata S.D., Gasparini S., \& Koubbi P., 2017. Biogeochemical regions of the Mediterranean Sea: An objective multidimensional and multivariate environmental approach. Progress in Oceanography, 151: 138-148.

Reyjol Y., Argillier C., Bonne W., Borja A., Buijse A.D., Cardoso A.C., Dufresne M., Kernan M., Ferreira M.T., Poikane S., Prat N., Solheim A-L., Stroffek S.S., Usseglio-Polatera P., Villeneuve B., \& van de Bund W., 2014. Assessing the ecological status in the context of the European Water Framework Directive: Where do we go now? Science of the Total Environment 497/498: 332-344.

Ridanovic L., Jurica D., \& Ridanovic S., 2017. Thermotolerant coliform counts and nutrient levels as indicators of water quality in sub-Mediterranean karst river. Journal of Coastal Life Medicine, 5: 182-186.

Robinson K.L., Luo J.Y., Sponaugle S., Guigand C., and Cowen R.K., 2017. A Tale of Two Crowds: Public Engagement in Plankton Classification. Frontiers in Marine Science, 4: 82.

Roca G., Alcoverro T., Krause-Jensen D., Balsby T.J.S., Van Katwijk N.M., Marba N., Santos R., Arthur R., Mascaró O., Fernandez-Torquemada Y., Pérez M., Duarte C.M., \& Romero J., 2016. Response of seagrass indicators to shifts in environmental stressors: A global review and management synthesis. Ecological Indicators, 63: 310-323.

Salas F., Teixeira H., Marcos C., Marques J.C., \& Pérez-Ruzafa A., 2008. Applicability of the trophic index TRIX in two transitional ecosystems: The Mar Menor lagoon (Spain) and the Mondego estuary (Portugal). ICES Journal of Marine Science, 65 : 1442-1448.

Schlitzer R, 2015. Ocean Data View, https://odv.awi.de

Segura-Noguera M., Cruzado A., \& Blasco D., 2016. The biogeochemistry of nutrients, dissolved oxygen and chlorophyll a in the Catalan Sea (NW Mediterranean Sea). Scientia Marina, 80: 
Bulletin de la Société des Sciences de Liège, Vol. 89, articles, 2020, p. 55 - 73

$39-56$.

Seitz R.D., Wennhage H., Bergström U., Lipcius R.N., Ysebaert T., \& Seitz R.D., 2014. Contribution to the Themed Section: "The Value of Coastal Habitats for Exploited Species" Ecological value of coastal habitats for commercially and ecologically important species. ICES Journal of Marine Science, 71: 18.

Santoso P.B., \& Halog A., 2017. Science Based Modelling for Supporting Integrated Coastal Zone Management. In Environmental Modeling with Stakeholders (pp. 307-325). Cham: Springer International Publishing.

Schernewski G, Neumann T., Stybel N., Behrendt H., \& Fenske C., 2009. Coastal eutrophication management: Lessons learnt from long-term data and model simulations. Coastline Reports 12: 101-111.

Serra P., Pons X., \& Saurí D., 2008. Land-cover and land-use change in a Mediterranean landscape: A spatial analysis of driving forces integrating biophysical and human factors. Applied Geography, 28: 189-209.

Tarragoni C, Bellotti P., Caputo C., Davoli L., Evangelista S., Pugliese F., Raffi R., \& Lupia Palmieri E., 2012. Coastal vulnerability and the implications of sea level rise between the cities of Pescara and Ortona (Adriatic Sea -Central Italy). Geophysical Research Abstracts EGU General Assembly, 14. Retrieved from : http://meetingorganizer.copernicus.org/EGU2012/EGU2012-9917-1.pdf

Teixeira Z., Teixeira H., \& Marques J.C., 2014. Systematic processes of land use/land cover change to identify relevant driving forces: Implications on water quality. Science of The Total Environment, 470: 1320-1335.

Uehara T., Niu J., Chen X., Ota T., \& Nakagami K., 2016. A sustainability assessment framework for regional-scale Integrated Coastal Zone Management (ICZM) incorporating Inclusive Wealth, Satoumi, and ecosystem services science. Sustainability Science, 11: 801812.

UNEP/MAP, 2007. Review Meeting of MEDPOL Monitoring Activities and the use of indicators Approaches to the assessment of eutrophication in Mediterranean coastal waters (first draft). UNEP(DEPI)/MED WG.321/Inf.6. http://195.97.36.231/acrobatfiles/07WG321_Inf6_eng.pdf

Valle M., Palà V., Lafon V., Dehouck A., Garmendia J.M., Borja A., \& Chust G., 2015. Mapping estuarine habitats using airborne hyperspectral imagery, with special focus on seagrass meadows. Estuarine, Coastal and Shelf Science, 164: 433-442.

Van Cappellen, P., Powley H.R., Emeis K.-C., \& .Krom M.D., 2014. A biogeochemical model for phosphorus and nitrogen cycling in the Eastern Mediterranean Sea: Part 1. Model development, initialization and sensitivity. Journal of Marine Systems 139: 460-471.

Van Hoey, G., Borja A., Birchenough S., Buhl-Mortensen L., Degraer S., Fleischer D., Kerckhof F., Magni P., Muxika I., Reiss H., Schröder A., \& Zettler M.L., 2010. The use of benthic indicators in Europe: From the Water Framework Directive to the Marine Strategy Framework Directive. Marine Pollution Bulletin, 60: 2187-2196.

Van Wijnen J., Ivens W.P.M.F., Kroeze C., \& Löhr A.J., 2015. Coastal eutrophication in Europe 
caused by production of energy crops. Science of The Total Environment, 511: 101-111.

Vollenweider R.A., Giovanardi F., Montanari G., \&Rinaldi A., 1998. Characterization of the trop hic conditions of marine coastal waters, with special reference to the NW Adriatic Sea: Proposal for a trophic scale, turbidity and generalized water quality index. Environmetris, 9: $329-357$.

Yasuhara M., \& Danovaro R., 2016. Temperature impacts on deep-sea biodiversity. Biological Reviews, 91: 275-287.

Welch S., \& Kennedy-Pipe C., 2004. Multi-level Governance and International Relations. In Multi-level Governance. Oxford University Press.

Zaucha J., Conides A., Klaoudatos D., \& Norén K., 2016. Can the ecosystem services concept help in enhancing the resilience of land-sea social-ecological systems? Ocean and Coastal Management. 124: 33-41.

Zoccarato L., \& Umani S.F., 2015. Major constrains of the pelagic food web efficiency in the Mediterranean Sea Major constrains of the pelagic food web efficiency in the Mediterranean Sea. BGD Biogeosciences Discuss, 12: 4365-4403. 
Appendix S1. Non-exhaustive list of social and economic factors that may influence decisionmaking around land-sea planning and the management of nutrient and sediment loading once the ecological situation are characterized using the decision tree.

\begin{tabular}{|c|c|c|}
\hline Topic & Element & Description \\
\hline \multirow[t]{5}{*}{$\begin{array}{l}\text { Culture } \\
\text { Politics }\end{array}$} & $\begin{array}{l}\text { Presence and } \\
\text { Use }\end{array}$ & $\begin{array}{l}\text { The presence of people in the region of interest, and their relative dependence on the } \\
\text { oceans for all of the services listed below. }\end{array}$ \\
\hline & Access & $\begin{array}{l}\text { Some communities may hope to limit access of outsiders to their coastal oceans; others } \\
\text { may have been excluded from parts of the coastal oceans they would like to regain } \\
\text { access to. }\end{array}$ \\
\hline & Culture & $\begin{array}{l}\text { Some communities may disproportionately value access to culturally meaningful } \\
\text { places, practices, and species. }\end{array}$ \\
\hline & $\begin{array}{l}\text { Existing } \\
\text { Legal Structure }\end{array}$ & $\begin{array}{l}\text { The feasibility and expected success of land-sea planning are partially dependent on } \\
\text { whether legal ontions exist to enact and enforce it. }\end{array}$ \\
\hline & Land Tenure & $\begin{array}{l}\text { In some regions, shifting communities and resource use in space may be relatively } \\
\text { feasible, while in others it may be all but impossible due to constraints on land use or } \\
\text { other cultural, political, and legal factors. }\end{array}$ \\
\hline \multirow[t]{3}{*}{$\begin{array}{l}\text { Revenue and } \\
\text { Livelihoods }\end{array}$} & Tourism & $\begin{array}{l}\text { Runoff and subsequent ecological degradation may reduce the tourism value of coastal } \\
\text { ecosystems, particularly coral reefs. }\end{array}$ \\
\hline & Fisheries & $\begin{array}{l}\text { Revenue and subsistence from coastal fisheries may be an important consideration, } \\
\text { although runoff will not necessarily decrease catch or value in the fishery. }\end{array}$ \\
\hline & Aquaculture & $\begin{array}{l}\text { Aquaculture has the potential to exacerbate runoff issues by increasing pollutant and } \\
\text { nutrient loads in rivers, or to mitigate them if suspension feeders are cultivated near the } \\
\text { river mouth. }\end{array}$ \\
\hline \multirow[t]{3}{*}{$\begin{array}{l}\text { Health and } \\
\text { Nutrition }\end{array}$} & $\begin{array}{c}\text { Harmful } \\
\text { Algal Blooms }\end{array}$ & $\begin{array}{l}\text { In some cases, nutrient loading leads to HABs, which have adverse impacts on human } \\
\text { health and on fisheries. }\end{array}$ \\
\hline & $\begin{array}{l}\text { Toxicity and } \\
\text { Pathogens }\end{array}$ & $\begin{array}{l}\text { Pollutants and pathogens transported by rivers have clear consequences for human } \\
\text { health and may originate from numerous sources including mines, sewage, and } \\
\text { aquaculture. }\end{array}$ \\
\hline & $\begin{array}{l}\text { Nutrition and } \\
\text { Food Security }\end{array}$ & $\begin{array}{l}\text { Land-sea planning may be more of a priority in communities that rely primarily on } \\
\text { seafood for nourishment, or that highly value having access to seafood in addition to } \\
\text { other food sources. }\end{array}$ \\
\hline \multirow{5}{*}{$\begin{array}{l}\text { Ecosystem } \\
\text { Services }\end{array}$} & Coastal & Habitats that buffer storms and filter runoff, such as salt marshes and wetlands, may \\
\hline & $\begin{array}{l}\text { Defenses/Buffer } \\
\mathrm{s}\end{array}$ & provide a valuable service to coastal communities. \\
\hline & Aesthetics & Community members may inherently value some coastal areas more than others, \\
\hline & $\begin{array}{l}\text { and Sense of } \\
\text { Place }\end{array}$ & possibly for their natural beauty or their historical meaning. \\
\hline & Recreation & $\begin{array}{l}\text { How local communities use the region recreationally, and which places they value for } \\
\text { this purpose, may be relevant. }\end{array}$ \\
\hline \multirow{6}{*}{$\begin{array}{l}\text { Watershed } \\
\text { Context }\end{array}$} & Land & Some watersheds may already regulate runoff-producing activities such as sewage \\
\hline & $\begin{array}{l}\text { Regulations of } \\
\text { Human }\end{array}$ & $\begin{array}{l}\text { disposal, agriculture, and deforestation, while others may have no controls on those } \\
\text { drivers. }\end{array}$ \\
\hline & Activities & \\
\hline & $\begin{array}{l}\text { Land } \\
\text { Regulations with }\end{array}$ & $\begin{array}{l}\text { Converse to the above consideration, some legislation enacted for entirely different } \\
\text { purposes may have unintended positive effects in the oceans, particularly when drivers }\end{array}$ \\
\hline & Ancillary & are mitigated upstream for terrestrial conservation purposes. \\
\hline & Marine Benefits & \\
\hline
\end{tabular}

